\title{
An Analysis of Performance Evaluation of Mutual Funds Based on Fund Nature: A Case of Mutual Fund Market of Pakistan
}

\author{
Muhammad Asim Gul \\ Institute of Management Sciences, Lahore \\ Javaria Qais Joiya \\ Director, Department of Sustainable Enviroment, University of Central Punjab, Lahore \\ Faisal Mustafa $(\mathrm{PhD})$ \\ Dean, Faculty of Management Studies, University of Central Punjab, Lahore
}

\begin{abstract}
Pakistan is an emergent country with a developing mutual fund industry. In Pakistan Mutual Fund existed since 1964 capital market conveying certain advantages like risk diversification, assured returns and professional management for the retail investors. There have been lack of evidence on the performance and determinates of performance in the Mutual Fund market of Pakistan. This research is performed to provide comprehensive evidence on the performance measurement of the Islamic and Conventional mutual fund industry in Pakistan. The research measured data of 102 mutual funds, which are divided into two isolated functional natures Islamic and conventional for the period of five years from 2010 to 2014. Performance of the funds is determined using performance measures of Sharpe measure, Treynor measure, Jenson's Alpha and Information ratio. The performance of two segregations of the funds were measured and compared on yearly bases. Further, using FamaFrench three-factor model along with an additional factor suggested by Carhart, the research measured abnormal returns on each of the fund and these abnormal returns were explained by fund characteristics of expense ratio, fund size, fund age and fund family size using cross sectional OLS estimation.

No significant performance differences that were found between Islamic and conventional funds. Treynor measure and Jenson's Alpha presented in-consistent and insignificant performance measurements. The research also provided evidence of a negative influence of expense ratio on mutual fund performance in Pakistan. The research will explore the mutual fund industry for better understanding and recommends devising alternative performance measurements and methods consistent with local context.
\end{abstract}

Keywords: Mutual Funds Association of Pakistan, Asset Management Companies, Mutual Funds, Performance evaluation, Islamic and Conventional Mutual Funds.

DOI: $10.7176 / \mathrm{EJBM} / 11-22-01$

Publication date: August $31^{\text {st }} 2019$

\section{Introduction 1}

Mutual Fund as part of the Financial Markets is a financial institution, with a particular scheme of collective investment directing small savers funds toward large investment portfolio and risk management. In other words, it is a pool of money that is collected from investors in the order to invest in activities that are more profitable that intends to maximize the wealth of investor's. Mutual funds also provide skilled management, reduced level of risk and approach to financial markets with a diversified portfolio. Performance evaluation of mutual funds is critical for both the investor and the fund manager. The investor need to know which fund will perform well in order to make the investment decisions, while a fund manager or the asset management company need to know about the performance of the funds in order to improve and develop more promising portfolio by adjusting their portfolio characteristics.

Mutual fund industry is growing rapidly around the globe. Therefore, Mutual funds as a viable investment options and a significant player in the financial markets have attracted a lot of research attention and comparative fund performance has been an active area of research for quite some time. Thus, lot of research has been done on different dimensions of mutual fund industry. Lobell (1961)Examined the structural analysis of mutual funds, which helped in understanding the structure and functions of mutual funds. While Friend, Brown, Herman, and Vickers (1962) analyzed the growth and performance of mutual funds along with their investment policies and impact of mutual funds on stock market for Security and Exchange Commission of USA, which later became a base for researchers in the field of mutual fund industry and helped the researchers to investigate and analyze different aspects of mutual fund performance.

\subsection{Pakistani Mutual Fund Industry 2}

The role of mutual funds is important in contributing towards the economic growth of developing countries like Pakistan. It is an essential instrument for creating capital, and directly affects the economy. In developed countries, 
there is lot of research on mutual funds. However, in Pakistan, mutual fund industry is not so mature and there is lacks of empirical work within this domain that is why lot of work is needed to be done in order to explain dynamics of mutual fund as to provide basic understanding and knowledge of the industry so that industry might grow.

Performance of mutual funds depends on many factors i.e. fund characteristics, risks involved, level of diversification, professional skills of managers and the liquidity (Ferreira, Keswani, Miguel, \& Ramos, 2013). These factors are also worth consideration in the local context as the mutual fund industry in Pakistan is witnessing a steady growth.

The value of mutual fund industry in Pakistan is multibillions and the history of the investment funds started in 1962 in the country. At first, by the introduction of an open-end fund by an Institute called NIT (National Investment Unit), which was regulated by the government. A significant development in investment industry occurred in late 2000, when the government decided to liquidate ICP (Investment Corporation of Pakistan), which was the regulatory authority of the NIT and decided to privatize the funds managed by the NIT.

The investment funds industry faced rapid growth when individuals were allowed to preserve their investment funds. Statistics for 2010, the total net assets of the investment fund industry was nearly two hundred million, indicating huge development in the industry, in comparison to the 2001 (89.44\%). The investment fund industry in Pakistan must try to earn more confidence of investors to increase the interest of investors in investment funds because it is an old problem, if the investment funds operate to Asset Management Company or to the interest of investors. The performance of anopen-ended mutual fund is better than the close-end funds, such as return on equity is concerned. In contrast, the open-end mutual funds face greater losses than to close by the end of the venture capital funds in 2008 and 2009. As opposed to the close-ended mutual funds in 2009, the open-end funds beard lot of loss. In 2010, the open -end fund acquired more return on equity by $6.32 \%$ than closed-end funds. Mutual Funds Association of Pakistan (MUFAP) is the trade body for Pakistan's multi billion rupees asset management industry. According to MUFAP there are 29 Asset Management Companies (AMC) having 247 mutual funds under 24 types of funds in Pakistan. Pakistan mutual fund industry is worth Rupee 404.266 billion in February 2014 according to MUFAP.

\subsection{Problem Statement 3}

In Pakistan, there is drought of knowledge in this domain of research. This research will also analyze the impact fund characteristics on the performance of mutual funds, which would be a new dimension in this domain for Pakistani mutual fund industry.

This research is an attempt to evaluate and compare the performance of different characteristics of mutual funds from Pakistani mutual fund industry. In the order to improve, theunderstanding of the factors that might have some influences the performance of mutual funds. Various aspects of mutual funds would be examined in this research as to explore the determinants of performance of mutual funds and provide understanding to the investors so that they might be able to make a guided investment decision.

In this research, different nature of funds will be compared and their performance would be measured in order to see which fund performs better and why. In this research, impact of liquidity and fund characteristics on the fund performance would also be examined. This research has two-fold importance, i.e. both theoretical and practical in nature.

\subsection{Objectives of the Research 5}

The main objectives of the research are:

1. To evaluate and compare the performance of all mutual fund schemes of Pakistani Asset Management Companies.

2. To examine effects of fund characteristics on fund performance.

3. To provide implications with regard to mutual performance in order to better guide investors and fund managers.

\subsection{Significance of the Study 6}

Theoretically, it would help the new researchers to investigate new avenues in mutual fund industry and practically, it is important for both investors and fund managers as using the findings of this research they would better be able to compare mutual fund performances and devise a better portfolio of their investment. This research will enable the investors to choose the right fund according to their needs i.e. risk and return credentials, keeping in consideration all the fund characteristics along with risks, costs and fund characteristics. Thus, this research would guide the investors in selecting and making the right investment decisions.

This research would also indicate towards the factors, which affect the performance and returns of mutual funds in Pakistan, which ultimately will help the fund managers to understand those factors so that they could develop better fund schemes after keeping in mind all those risks and factors affecting the performance of mutual funds. 
This research will also help the fund managers and asset management companies in selecting right portfolio for a fund scheme and in understanding the impact of timing ability and liquidity of funds on the performance of mutual funds. This research will help the mutual fund managers to understand in a better way the composition of a fund and to develop well-managed and stable funds. This research will become a base for other researches to investigate and help them to understand the basics regarding mutual fund performance evaluation.

\section{Review of Literature 1}

This study evaluates the performance of different funds and compares the performance of these funds on the bases of different fund characteristics. Most of the literature is taken from foreign studies conducted on mutual funds because in Pakistan, not much work has been done on this industry. The studies available are narrow in focus and mostly compare mutual fund performance on a limited sample base. This part of the study summarizes the findings of the past studies relevant to the topic of the study.

Rinne and Suominen (2014)Investigated the impact of liquidity and cost of immediacy on the returns of mutual funds. For the purpose of this research, a sample of equity funds was taken from US mutual fund market. The sample excluded the index funds. The sample period was considered for a period of 23 years ranging from 1984 to 2010 . Some equity funds were found to earn returns to the investors that demand immediacy by providing liquidity to them. It was also found that cost of immediacy affected the performance and returns of the mutual funds sampled. Investors who want more liquid and less immediacy costs invest in more liquid funds only. While other funds suffer due to the immediacy costs as investors calculate actual returns of mutual funds by subtracting such costs from the shown returns of mutual funds. Therefore, the out performing funds may give lower returns after deducting such costs. It was concluded that cost of immediacy and liquidity are the most important factors for investors in calculating performance and returns of the mutual funds. It was further elaborated that future alphas of mutual funds could be predicted by historical costs of the mutual funds.

Hayat and Kraeussl (2011) took a sample of 145 Islamic equity funds from Asia over a period 2000 to 2009 in order to examine the risk and return characteristics of these Islamic equity funds. The portfolio holdings would be halal if they follow three financial criteria which state that total debt over 12-month average capitalization, cash plus interest bearing securities over 12 month average market capitalization and accounts receivables over 12 month average market capitalization should be less than 33\%. The performance of Islamic equity funds was evaluated against the conventional and Islamic benchmarks. CAPM was used to measure risk and return characteristics and performance of mutual funds while they used Treynor and Mazuy (1966) model and market timing testing procedure proposed by Jiang (2003) in order to measure and test timing ability of fund managers. The purpose of this study was to analyze the performance of Islamic mutual funds. They found that Islamic equity funds underperformed in comparison to those of Islamic and conventional mutual fund benchmarks. Islamic equity funds composed of local stocks performed better than those composed of international stocks did. It was also found that Islamic equity funds were poor market timers and they had some specific risks that were not present in conventional investments, which were Sharia laws, lack of track record, low working capital companies and suboptimally leveraged companies, but Islamic equity funds did not have any downside risk. It was concluded that Islamic index trackers and Islamic exchange traded funds were a better investment option than Islamic equity funds.

Avramov and Wermers (2006) took a sample of 1301 open-ended non-load domestic equity funds from U.S. mutual fund industry over a period from 1975 to 2002 for investigating investment decisions in mutual funds when future returns are predictable. The predictability included manager skills, fund risk loading and benchmark returns. Funds were divided into four categories on the bases of investment objectives. These categories were Aggressive growth, Growth, growth \& Income and Metals \& Others. CAPM was used for measuring returns and performance while future returns were measured by using dividend yield, spread, 3-month T-bill yield and other variables identified by Fama and French (1989). They divided investors into 3 groups on the bases of investment styles that were Dogmatist, Skeptic and Agnostic. They found a significant relationship between the manager skill predictability and the fund returns. While fund risk loading and benchmark return, predictability did not show a significant relation. They concluded that dominant source of investment profitability was predictability in manager skills hence; active management improved the fund performance. They also concluded that industries were also important in finding outperforming funds that means industry selection is also an important factor in determining future mutual fund performance and returns.

Mansor and Bhatti (2011) took a sample of 478 mutual funds from Malaysia for a period starting from 1996 to 2009 for evaluating the performance of mutual funds. They compared the performance of Islamic mutual and the conventional mutual funds by doing a risk and return analysis for which they took 128 Islamic mutual funds and 350 conventional mutual funds. Performance of funds was evaluated by taking monthly aggregate returns. They found that these two portfolios performed better than the market portfolio in the said time period while Islamic mutual funds have yielded less returns in comparison to the conventional mutual funds. They found that Islamic mutual funds were riskier than those of conventional mutual funds were and their standard deviations 
showed a significant difference that caused changes in returns of these mutual funds. They concluded that both Islamic and conventional mutual funds were primarily dependent on the market portfolio and Islamic portfolio was mirrored to the market movements. Both conventional and Islamic mutual funds performed well but the returns of conventional mutual funds were a little higher than those of Islamic mutual funds.

Humphrey and Lee (2011) took a sample of 623 mutual funds from Australian mutual fund industry out of which 593 were conventional funds while 30 were socially responsible funds for a sample period from 1996 to 2008 in order to evaluate the performance, risk and returns of socially responsible mutual funds. Conventional funds having resemblance on the bases of characteristics like age, size, availability and fund style were compared with socially responsible funds. Fama and French (1992) and Carhart (1997) model was used while for measuring returns and performance they used annual returns and Sharpe ratio. They concluded that socially responsible funds provide similar returns as compared to those of the conventional funds. It was found that screening intensity of mutual funds have no significant impact on the total return of a fund.

Ornelas, Silva Júnior, and Fernandes (2012) investigated that choice of performance measure matter for ranking mutual funds by taking a sample of 21,246 mutual funds from U.S mutual fund industry and the sample period started from 1998 to 2008. They used Spearman's ranking correlation for ranking mutual funds on the bases of their characteristics. They used 14 different performance measures for comparison which were Sharpe ratio, Omega Ratio, Sortino Ratio, Upside potential ratio, Kappa Ratio, Calmar ratio, Sterling ratio, Burke ratio, Dowd ratio, Conditional Sharpe ratio, generalized sharpe ratio, Treynor index, Appraisal ratio and MPPM (manipulation proof performance measure). The purpose of this study was to compare and examine all the measure used for measuring performance and conclude the most efficient and accurate measure. They found that all those performance measures that were based on absolute reward-risk ratios had similar ranking. While the results of MPPM, with upside potential ratio and appraisal ratio were different from those that measures using absolute reward-risk ratios, tit was concluded that the performance measure selection was very important for selection and ranking of mutual funds.

Khorana and Servaes (2012) analyzed factors that drive market share in mutual fund industry. For this purpose, they included all the mutual funds and the sample period started from 1976 to 2009. The purpose of this study was to find all the major factors due to which a specific mutual fund or a fund family captures market share. They examined market share drivers in two aspects, one of them was based on the price and the other one was based on aspects other than price. They found that fund expenses and loads play a vital role in the investment decision of an investor so pricing is one of the major determinants of market share capturing factor. While non-price aspect was based on the fund family characteristics like prior performance, size, age, fund ratings, asset concentration, level of active management, innovation and marketing \& distribution costs. They calculated market share by dividing sum of all assets under management in each family by sum of all assets under management in the industry. It concluded that both price competition and product differentiation were important in capturing market share. Fund families with economy of scale and lower costs gained more market share while fund families with less innovation and variety failed to obtain market share. It was also concluded that fund families compete on both price and product differentiation.

Da, Gao, and Jagannathan (2011) analyzed the impact of impatient trading, liquidity and stock selection on the performance of mutual funds by taking a sample of 4,654 funds for a period starting from 1983 to 2004 . They divided funds into aggressive growth, growth and growth \&income categories. The fund characteristics under observation were age, turnover, expense, total net asset, active share and net fund flows. They decomposed the portfolio selection into liquidity absorption, impatient trading and liquidity provision. They found that future performance of funds or portfolios, composed of such stocks that were sensitive to information events, can be predicted on the bases of past performance. It was also found that impatient trading caused superior performance of mutual funds. They concluded that liquidity provisions were important for new income funds while impatient trading was significant for growth-oriented mutual funds.

Ferreira et al. (2013) took a sample of 16,316 open-end equity funds from 27 countries from 1997 to 2007 and investigated the performance determinants of mutual funds. The purpose of the study was to examine the effect of fund characteristics and country characteristics on the performance of the fund. Fund performance was measured by Fama and French (1992) three-factor model and Carhart (1997) four-factor model. Fund characteristics included fund age, fund size, fund family size, total expenses, total load, flows, past performance, management structure and number of countries in which fund was sold. Country characteristics were further divided into five groups in accordance with the economic development, concentration, investor protection \& quality of legal institutions, financial development and mutual fund industry development \& concentration of relative country. It was found that equity funds underperform the market. It was concluded that country characteristics were more effective than the fund characteristics as to explain fund performance. It was also found that home-trading environment and the quality of legal institutions had a positive impact on the performance of the mutual funds across countries.

Bodson, Cavenaile, and Sougné (2013) took a sample of 2780 mutual funds from 1970 to 2010. Out of 2780 funds, 1570 were dead at the end of 2010. They excluded Exchange Traded funds and the funds with returns of 
less than 1 year and only included local equity funds. They investigated mutual fund market timing with respect to liquidity, volatility and return. They used asset-pricing model of Fama and French in order to measure market timing ability of mutual fund managers. They also used Market excess return, size, risk free rate, book to market value. GARCH $(1,1)$ was used on market return in order to get market volatility measure. Measurement method proposed by Pastor and Stambaugh (2001) was used to measure market wide liquidity. It was found that dead funds show lower volatility and liquidity timing skills while live funds show higher volatility and liquidity timing skills. The study concluded that apart from market timing ability of the fund managers, there were other factors that might have positive or negative affect on market exposure in mutual fund market.

Kaushik, Brinckman, and Rose (2013) Constructed a sample of 1,374 actively managed equity funds from USA fund market in order to examine the performance of these funds and to examine the performance evaluation methods and the criteria used for fund selection by the investor. The sample period consisted of 12 years from 2000 to 2011. The purpose of this study was to help the investors in selecting right type of fund and to help them in evaluating the performance of funds and reaching their desired goals. Fund performance was measured by using excess returns based on characteristics like small cap funds, large cap funds, value, size, net asset values, tenure, expense ratio etc. They identified and separated the characteristics of both top performing and low performing funds in order to help the investors in their investment decisions. It was concluded that top performing funds had a lower asset turnover and expense ratio, while longer tenure of fund manager and small cap funds perform better and had higher excess return.

Chou (2013) took a sample of 51,975 mutual funds including both domestic and foreign mutual funds of 28 countries for the period from 1998 to 2007 to evaluate and compare the portfolio preferences of both domestic and foreign mutual funds for each of emerging and developed markets. Portfolio preferences were divided into firm characteristics, country level institutions and the information environment of firm. Firm characteristics were measured by using firm size, stock return, book to market ratio, dividend yield, firm age, sales growth, closely held ownership, debt to asset ratio, cash holding, return on equity and stock return volatility. While, accounting standards, analyst coverage, accruals, forecast dispersion, earning correlation, forecast errors and earning smoothing were used to measure firm's information environment. Lastly,GDP per capita, GDP growth, and GDP growth volatility, trade to GDP ratio, stock market capitalization to GDP ratio and stock market volatility measured the country level characteristics. The study found that economic development has a significant impact on the preferences for both domestic and foreign mutual funds while, each of this fund has a different preference towards firm's information environment and firm's characteristics. It was concluded that country characteristics were important factor for fund type preference and investment decisions.

Wagner and Winter (2013) investigated the impact of liquidity and idiosyncratic risk on the performance of mutual funds. For this purpose, they took a sample of 528 mutual funds from European stock market that were actively managed. The sample was taken for a period of 8 years from 2002 to 2009. Multifactor models of Fama and French (1993) and Carhart (1997) was used for evaluating performance of the funds but liquidity and idiosyncratic risk were also included in order to check their impact on the performance of the mutual funds. Six factors were examined which included market excess return, size, valuation, momentum, idiosyncratic risk and illiquidity in relation to performance of mutual funds. Market excess return was measured by taking difference of market index and risk free rate while they calculated valuation factor by taking difference of growth index and the value. While differences of top and bottom indices for measuring other factors. It was concluded that liquidity and idiosyncratic risk significantly influence the performance of mutual funds so instead of Fama-French four-factor model, this six-factor model should be used as it has more explanatory power with regard to performance of mutual funds.

Pukki (2012) took a sample of 21,500 mutual funds of UK from 1980 to 2010 . The sample was divided among 3 types of mutual funds i.e. fixed income funds, open-ended equity funds and balanced funds. The purpose of the study was to examine fund's ability to time liquidity in the market. Only one share class of a mutual fund family was considered while the index funds were excluded as they are used to replicate the benchmark index's performance. Trading volume and market turnover were used as a measurement of market liquidity along with a third measurement i.e. Sadka permanent-variable liquidity measure. Fama-French factors were used to measure the returns in case of size and value but Carhat momentum factors were used to measure excess returns. A significant and positive relation of market liquidity with trading volume and turnover was found while turnover had an insignificant relationship with market returns. The study concluded that mutual funds had a positive liquidity timing ability and among all mutual funds, growth funds showed greatest liquidity timing skill.

Prajapati and Patel (2012) examined the performance of mutual funds in India. A sample of five asset management companies was taken for the period of 5 years from January 2007 to December 2011 as to compare and evaluate the performance of different types of mutual funds in India. For evaluation Fama French's threefactor model, Jensen's model, Treynor's ratio, risk-return analysis, performance index, Sharp's measure and ratio analysis were used. The study showed that the mutual funds of India had performed well during 2007 to 2011 and had yielded better returns. It was also found that the selected funds were less volatile than the index and their 
performance matched the benchmark as their beta was close to one.

Raza, Raza, and Zia (2011) examined the performance of mutual fund industry of Pakistan by taking a sample of 12 asset management companies from 1999 to 2009. Net asset value (NAV), Sharpe's measure, Treynor's measure and Jensen's measure were used to evaluate the performance of mutual funds. Mutual funds were classified into small cap fund, value fund, large cap fund and balanced funds. This classification was done by using four models namely; Fama-French 3 factor model, Brown and Goetzmann's model, Sharpe's model and Barra Swiss 8 factor model on the basis of different dimensions like size, book to market ratio, return on growth, global timing, international funds, return on income, value, yield, volatility, financial leverage etc. Impact of Market portfolio, dividends and Pakistan investment bonds on the performance of the mutual funds was also examined by the study. A significant and positive impact of Market portfolio and Pakistan investment bonds on returns of the mutual funds was found. Dividends on the other hand yielded an insignificant relationship on the returns of the funds because net asset values decreased after the payment of dividends at the end of the year.

Huang, Sialm, and Zhang (2011) investigated the impact of risk shifting on the performance of mutual funds and the mechanism of risk shifting. For this purpose, they took a sample of 2,335 mutual funds for the period from 1980 to 2006. Only domestic equity funds were included in the sample while all other funds like balanced funds, bonds, money market, international and the index funds were excluded from the sample. The risk shifting of funds was measured by comparing their current holding volatility with the past volatility also called holding-based measure of risk shifting. It was found that funds having stable risk levels perform better than those having increased risk level do. Moreover, funds which expected better returns after risk shifting, had a negative correlation and performed poor after increase in risk. It was concluded that risk-shifting behavior is caused due to agency problems and not by the investment opportunities and risk could be shifted either by diversification or by holding assets having different risk properties.

Pollet and Wilson (2008) examined the impact of size on the performance of mutual funds by considering a sample span from 1975 to 2000. In 1975, the number of funds was 253 and it increased to 1421 in 2000. After excluding foreign funds from sample, it found that with increase in flows the funds do not diversify much. The change in assets under management did not influence the portfolio, no change or diversification occurred due to that change, and the funds invest in the same existing portfolio when there is no liquidity constraint. While in case, where there were liquidity constraints, the funds diversify when they grew and when they received new money they scaled less. They concluded that the funds should change the portfolio when the assets under management change and the diversification should be made in response to fund growth. Small cap funds performed well when diversified. They concluded the fund family and the number of sub-funds in a fund family might affect that fund's portfolio strategy.

Swinkels and Tjong-A-Tjoe (2007) investigated the question that whether mutual funds can time investment styles. For this purpose, they took a sample of 153 US based mutual funds with a blend of different investment styles by using Morning star style box classification. The sample period was from 2001 to 2005. The purpose of this study was to examine the ability of mutual fund managers to rotate between different investment styles. These investment styles were based on different characteristics like market capitalization, price momentum and the valuation ratios. Two performance evaluation models namely Treynor and Mazuy (1966)\&Henriksson and Merton (1981) were employed to evaluate the performance of the mutual funds. Mutual funds were found to be able to predict the momentum style and the valuation. It was also found that mutual funds were not able to predict the magnitude of that change caused by momentum style and the valuation while funds were unable to deviate and rotate between stocks with small and large market capitalization. The study on the whole concluded that mutual funds could time stock market and the mutual funds.

Chen, Hong, Huang, and Kubik (2004) took a sample of 3,439 U.S equity funds for the period from 1962 to 1999 in order to examine the impact of fund size on its performance. They used CAPM of Sharpe (1964), three factor model of Fama and French (1993) and the momentum model of Carhart (1997) to measure the performance of mutual funds. Researcher used TNA (total net asset) value to measure the fund size. An insignificant relation between fund size and fund performance was documented by the study. Thus it was concluded that fund size do not erode fund performance. Fund performance of small cap stocks was more affected by fund size than large cap stocks that showed that changes in fund performance by fund size were due to liquidity. They also found that fund performance was eroded by liquidity and diseconomies of the organizations.

Idzorek, Xiong, and Ibbotson (2012) examined the liquidity style of mutual funds by taking sample from US and non-US equity mutual funds for a period starting from 1995 to 2009 . The purpose of this study was to investigate that mutual funds having less liquid stocks outperform the mutual funds having move liquid stocks. Turnover measure was used for measuring liquidity. Mutual funds were categorized into 16 groups on the basis of Morningstar division. Out of which nine were size valuation style boxes; three valuation based columns (e.g. value, core and growth); and three were size-based rows (e.g. large, mid and small). It was found that mutual funds holding less liquid stocks outperformed those mutual funds comprising of more liquid stocks and it happened because less liquid funds showed superior performance in down markets. It concluded that liquidity investment 
style was present in mutual funds that lead to differences in performance of mutual funds.

Cremers and Petajisto (2009) took a sample of 2,650 mutual funds from 1980 to 2003 in order to measure active management by developing a new measure for predicting performance of mutual funds. They called this new measure Active Shares, which is the portfolio holdings deviation from its benchmark index. Active management was measured on two dimensions that were active share and tracking error where tracking error is the standard deviation of the difference between the fund returns and its benchmark returns. They measured active management level by using active share by comparing the holdings of mutual funds with that of the benchmark holdings. Tracking error for different types of active management is different, that is why they used active share along with tracking error in measuring active management. The impact of fund size, expense and turnover on active management was also examined. It was found that highly active share funds outperform their benchmark indexes irrespective of the expenses. They concluded that most active stock pickers generally create value for investors and fund size had a significant impact on active management of mutual funds.

Huang, Sialm, and Zhang (2011) analyzed the impact of risk shifting on the fund performance by taking a sample of 2335 actively managed equity funds from U.S. market for a period starting from 1980 to 2006 . In order to measure risk-shifting behavior of mutual funds they used holding-based measure that was the difference between current holdings volatility of a fund and its past-realized volatility. Where current holdings volatility was measured by taking standard deviation of the recent disclosed holdings of that fund while past realized volatility was measured by taking standard deviation of the actual returns of the fund. The risk shifting measure would be positive if the fund had riskier recent holdings than those of actual holdings of that fund. The purpose of the study was to investigate the level of risk shifting by fund managers for increasing their incentives and the impact of that risk shifting on the performance and returns of mutual funds. It was found that the funds having higher expense ratios perform better. It was concluded that funds with stable risk performed well while funds with risk shifting behavior underperformed. Funds expecting more benefit from risk shifting, experienced more risk and performed poor.

Chen, Hong, Jiang, and Kubik (2013) took 37227 fund-year observations for a period starting from 1994 to 2007 , in order to investigate the impact of mutual fund management outsourcing on the incentives and the performance of mutual funds. The purpose of the study was to compare performance and incentives of outsourced and internally managed mutual funds. The study examined the impact of managerial outsourcing on performance and incentives. It was found that the funds with internal management performed better than the outsourced management. They concluded that outsourced funds took less risk that caused poor performance. It was concluded that outsourced management caused poor performance of the mutual funds so a firm should rely on higher incentives to its internal management in order to get higher returns from the mutual funds.

Bailey, Kumar, and $\mathrm{Ng}$ (2011) investigated the impact of behavioral biases of mutual fund investors on fund performance. For this purpose, they took a panel data of 6 years from 1991 to 1996 including monthly trades and the monthly portfolio of US discount brokerage investors. The database used in this study was used in many studies including Odean (1998a) and Odean (1998b). New measures such as attention to news, fund level familiarity and tax awareness were used in this study along with other traditional measures like demographic and behavioral characteristics. The purpose of the study was to test the impact of behavioral biases on the fund performance and returns. Demographic factors like age, marital status, and family size, professional dummy and retired dummy were used as control variables. They found that the investors with behavioral bias made poor decisions in fund selection as a result their selected fund did not perform well and they followed the trend. Such investors made poor decisions about fund style, trading frequency, timing and expenses. It was found that behaviorally biased investors did not have managerial skills and the past performance was irrelevant in their decision-making. Such investors were divided into five groups on the bases of their stereotype characteristics that were Gambler, Mature, Overconfident, Smart and Narrow Framer.

Sialm and Starks (2012) took a sample of 1348 equity funds for a period from 1997 to 2006 and included 6811 fund-year observations for testing the tax clientele's effect on mutual fund performance. The purpose of the study was to examine the effect of tax-deferred assets on the mutual fund strategies and the outcomes of such strategies. It was concluded that funds held by the taxable investors were more tax efficient while tax-deferred funds were less tax efficient. Fund managers prefer outcomes while the taxable investors prefer such funds, which are more tax efficient. Hence, fund strategies and their performance mainly rely on the investor preference about tax efficient funds and the fund manager's incentives. Fund managers with tax efficient strategy had constrained investment opportunity which might affect the fund performance.

Edelen, Evans, and Kadlec (2013) investigated the impact of trading cost on mutual fund performance by taking a sample of 1758 open-ended domestic equity funds for a period starting from 1995 to 2006 consisting portfolio holdings data on quarterly bases. Trading volume, brokerage commission and bid-ask spread were considered in finding trading cost and to measure the trading cost, per unit cost of each trade was multiplied with dollar value of each trade. Position adjusted turnover was introduced as a measure which was effective in case where proxy for turnover failed to identify this effect and turnover failed to line up with the microstructure theory. It was found that trading cost had a significant relation with the fund performance. It was concluded that trading 
cost was as important as the expense ratio was for analyzing the fund performance.

Parida and Teo (2011) took a sample of 2901 US open-ended domestic equity funds for a period from 1990 to 2008 in order to examine the impact of portfolio disclosure on mutual fund performance. Data was divided into two parts on the bases of portfolio disclosure, one was 1990-2003 and second 2005-2008 because U.S government stated the law of quarterly portfolio disclosure in 2004 and before which semi-annually disclosure was made. Different fund characteristics like fund size, liquid and illiquid holdings were analyzed for examining the impact on fund performance. It was found that semi-annual funds having abnormal returns in the past outperformed the quarterly-funds while the semi-annual funds having illiquid assets underperformed in comparison to semi-annual funds having liquid assets. It was concluded that holdings disclosure had a significant but negative relation to the mutual fund performance.

Cremers, Ferreira, Matos, and Starks (2011) took a sample of 24492 equity mutual funds across 32 countries over a period starting from 2002 to 2010 in order to examine the impact of indexing for active management on equity mutual funds. Holdings based was used as a measure for classifying active funds into closet indexers or truly active and to explain the classification of fees charged by the Asset management companies to the investors. The measure used for measuring prevalence of closet indexing among the active funds was developed by K. J. M. Cremers and Petajisto (2009). They uses total expense ratio and loads for measuring fees and expenses charged which also include audit, legal, management and administration fees but exclude front and back end load. To calculate total shareholder costs per year, they used the measure used by Khorana, Servaes, and Tufano (2009) where expense ratio total was added to one fifth of the front-end load after considering that an investor holds a fund for nearly 5 years. They used market share and total shareholder cost for measuring competition in a country's mutual fund industry. They also examined the relationship between indexing and the characteristics of a country's mutual fund industry. They found that countries with weak regulations and laws have less explicit indexing and concluded that explicit indexing improves the level of efficiency and competition among the mutual fund industry of a country.

Elton, Gruber, and Blake (2012) examined the impact of fund size on fund performance by taking a sample of 3000 domestic common stock funds for the period starting from 1999 to 2009. They used Famma French model along with Famma French plus bonds and momentum model. The cash flow was measured by subtracting total net asset at beginning from total net asset value at the end of a year, then added rate of return in it, and at last divided it by total net asset value at the beginning. They also used measures like family size, turnover ratio, fund size and expense ratio. They found that growth in fund size erodes predictability and performance slowly and size is not of much importance for predicting returns and performance.

Daniel, Grinblatt, Titman, and Wermers (1997) developed a new performance measure based on characteristics of funds and took a sample of 2500 equity funds for a period starting from 1975 to 1994 in order to apply this measure. This performance measure used benchmarks, which were based on the characteristics of the stocks involved in the composition of a fund or portfolio. The characteristics used were book to market, capitalization and some prior-year return characteristics of those stocks. Two measures were developed based on these characteristics which were namely characteristic timing and characteristic selectivity which detected the timing ability of fund managers based on these characteristics and fund manager ability to select outperforming stocks based on the above mentioned stock characteristics. They used Jensen measure using Carhart (1997), Grinblatt, and Titman (1993) for measuring performance of mutual funds. They found that performance of mutual funds depends on the characteristic selection ability but characteristic timing ability did not have a significant impact on the performance of mutual funds.

The review suggested that cost of liquidity is an important factor for investors in calculating the returns of mutual funds and risk could be shifted either by diversification or by holding assets of different risk properties. Fund characteristics are not much significant and there is very less impact on the fund performance due to the fund characteristics like fund size, fund age, fund family size, total expenses and manager structure. Some fund characteristics like expense ratio and asset turnover have significant impact on fund performance while other fund characteristics have insignificant relationship with fund performance. It was found the fund family and number of sub-funds in a fund family could effect that fund's portfolio strategy. Moreover, the fund size had an insignificant relationship with the fund performance. While dividends showed an insignificant relationship with the fund returns because NAVs decrease after payment of dividends at the end of year. In Pakistan, the performance of mutual funds was poor during the period 2007 to 2011 and the equity funds outperformed the income fund.

\section{Research Methodology 1}

We will evaluate and compare the performance of different funds in this exploratory research. Moreover, the impact of liquidity on performance will also be examined in this research. For this purpose the methodology will be divided into two parts i.e. performance and impact of firm characteristics and liquidity on the fund performance. 


\subsection{Performance Comparisons 2}

Performance of each fund will be measured by using four ratios which are Sharpe (1966), Treynor and Mazuy (1966), Jensen (1968) and Information measure of Goodwin (1998). After evaluating the performance of each fund, we will compare all the funds on the bases of their performance. Model for each measure is given below:

Sharpe ratio $=(\mathrm{Rp}-\mathrm{Rf}) / \delta P$

Sharpe ratio is calculated by subtracting the risk-free rate (3-month T-bill rate) from the rate of return of a portfolio, and then dividing the result by the standard deviation of the portfolio returns. Higher the Sharpe ratio, the better will be the performance.

\section{Treynor measure $=(R p-R f) / \beta p$}

Where;

$R p=$ the observed average fund return where the average has been calculated through the geometric mean (GM)

$R f=$ the average (calculated through GM) risk free return

$\beta \mathrm{p}=$ the non-diversifiable risk (systematic risk) of the portfolio.

Treynor measure defines the relationship between portfolio returns and market rates of returns while beta coefficient is the volatility measure of a stock, portfolio or the market.

\section{Jenson's alpha $=\mathbf{R p}-[\mathbf{R f}+\boldsymbol{\beta}(\mathbf{R m}-\mathbf{R f})]$}

Jenson's alpha is the difference of the portfolio return and the return predicted by the CAPM. The positive $\alpha$ indicates good performance whereas a negative $\alpha$ indicates poor performance.

Information measure $=$

$$
I R_{j}=\frac{\bar{R}_{j}-\bar{R}_{b}}{\sigma_{E R}}=\frac{\overline{E R}_{j}}{\sigma_{E R}}
$$

Where:

$I R j=$ the information ratio for portfolio $\mathrm{j}$

$R j=$ the average return for portfolio $\mathrm{j}$ during the specified time period

$R b=$ the average return for the benchmark portfolio during the period

$\sigma E R=$ the standard deviation of the excess return during the period.

Information measure was proposed by Goodwin (1998). It is also called appraisal ratio which measures the average return of a portfolio in excess of benchmark portfolio divided by the standard deviation of that excess return.

\subsection{Model 3}

Performance will be measured by calculating the excess returns of funds in case when we would be examining the impact of fund characteristics on the fund performance. For calculating return, we will use daily NAVs (net asset values) of all funds calculated on monthly bases in this research. Asset pricing model developed by Fame and French (1992) augmented with the momentum factor of Car hart (1997) will be used in order to examine the impact of liquidity and fund characteristics on fund performance.

$$
R_{i, t}=\alpha_{i}+\beta_{1, i, t} M K T_{t}+\beta_{2, i} H M L_{t}+\beta_{3, i} S M B_{t}+\beta_{4, i} M O M_{t}+\varepsilon_{i, t}
$$

Where:

$\alpha=$ Excess returns on the portfolio

MKT $=$ Market index returns

$\mathrm{SMB}=$ Return on small portfolio minus return on big portfolio

$\mathrm{HML}=$ Return on high book to market portfolio minus return on low book to market value portfolio

$\mathrm{MOM}=$ Momentum i.e. Return on past winner portfolio minus return on past loser portfolio

Fund characteristics will be the independent variables. Fund characteristics included in the research are expense ratio, age of the fund, size of the fund and family fund size (Chen et al., 2004; Ferreira et al., 2013; Yan, 2008; Huang et al., 2011; Sadka, 2012; Robinson \& Sensoy, 2011). These fund characteristics are regressed against excess returns as measured by model provided above.

\subsection{Data Sources 4}

Data will be collected from secondary sources. Data will be obtained from Securities and Exchange Commission of Pakistan (SECP), Mutual fund association of Pakistan (MUFAP), Pakistan credit rating agency (PCRA) and fund manager reports (FMRs) of Asset Management companies (AMCs). Only open-ended mutual funds were considered for the research. Further funds started recently or less than age of four were also excluded from the research. Final set of mutual fund contained 102 open-ended mutual funds. Three-month data relating to T-bill rates will be obtained from state bank of Pakistan. Market risk rate will be calculated based on opening and closing values from KSE-100 index and Karachi Stocks. 


\subsection{Analysis Procedure 5}

Performance of funds will be calculated and compared using ANOVA and independent sample test. For comparisons, funds would be divided according to their nature i.e. Islamic, conventional, and according to their type i.e. aggressive fixed income, asset allocation, balanced, equity, and fund of funds, income, index tracker and money market. Along with ANOVA and independent sample t-test, descriptive techniques of data analysis would be used such as mean, standard deviation and mean differences. Later in the research, the impact of fund characteristics will be established in order to check the importance of different fund characteristics and using cross sectional OLS model would do it.

\section{Data Analysis 1}

This part of the analysis provides the comparisons of the fund performance using measures like Sharpe measure, Treynor measure, Jensen's Alpha measure and information measure. Subsequent discussion of this part is divided according to these measures.

\subsection{Sharpe Measure 2}

Sharpe (1966) devised a composite measure evaluate the performance of mutual funds. This measure provides risk-adjusted measurement of the performance of the mutual fund and is obtained by subtracting mutual fund returns from risk free rate of return i.e. three month T-Bill rate and dividing it with standard deviation of the mutual fund returns. Mutual funds were distributed according to their nature and type. Nature distribution was done by seeing as to whether the fund was Islamic i.e. Shariah compliant or Conventional. Apart from that funds were also segregated according to eight distant types i.e. Aggressive fixed income funds, Asset allocation funds, Balanced funds, Equity Funds, Fund of Funds, Income funds, Index Tracker funds and Money Market funds. Table 1 and Table 2 provide the year wise comparison of the Mutual fund comparison according to their nature.

Table 1. Sharpe Measure of Performance Fund Nature Wise

\begin{tabular}{|c|c|c|c|c|c|c|c|}
\hline & Nature & $\mathbf{N}$ & Mean & Std. Deviation & Mean Difference & $\mathbf{t}$ & Sig. \\
\hline \multirow[t]{2}{*}{2010} & Islamic & 28 & -0.57 & 0.65 & & & \\
\hline & Conventional & 74 & -0.51 & 0.43 & -0.06 & -0.54 & 0.59 \\
\hline \multirow[t]{2}{*}{2011} & Islamic & 28 & -0.61 & 0.22 & & & \\
\hline & Conventional & 74 & -0.61 & 0.32 & 0.01 & -0.54 & 0.92 \\
\hline \multirow[t]{2}{*}{2012} & Islamic & 28 & -0.55 & 1.52 & & & \\
\hline & Conventional & 74 & -0.56 & 1.78 & 0.01 & 0.03 & 0.98 \\
\hline \multirow[t]{2}{*}{2013} & Islamic & 28 & -2.16 & 5.33 & & & \\
\hline & Conventional & 74 & -1.66 & 3.94 & -0.50 & -0.52 & 0.60 \\
\hline \multirow[t]{2}{*}{2014} & Islamic & 28 & -0.45 & 0.47 & & & \\
\hline & Conventional & 74 & -0.27 & 0.38 & -0.18 & -1.98 & 0.05 \\
\hline
\end{tabular}

Sharpe ratio was calculated on year wise bases for the period under consideration i.e. 2010 to 2014. Out of total 102 mutual fund considered 28 represented Islamic or Shariah compliant segment while remaining 74 were of conventional segment. Mean Sharpe measure value of Islamic funds for year 2010 was -0.57 with a standard deviation of .65 , while mean Sharpe measure value of conventional funds was found to be -0.51 . The mean difference between both values in 2010 was -0.06 along with a t-statistics of -0.54 , which indicates that the performance difference between Islamic and conventional fund in 2010 was insignificant. Mean Sharpe measure value for both Islamic and conventional funds amounted to an average of -0.61 along with a respective standard deviation of .22 and .32 in 2011 indicating no performance differences between Islamic and conventional funds in 2011. Further, Islamic funds yielded mean Sharpe value of -0.55 and conventional funds averaged at -0.56 (Mean difference $=.01$ ) in 2012. The t-statistics for the mean difference was .03, implying the difference to be insignificant. For year 2013, Islamic funds yielded a Sharpe measure average of -2.16 (Standard deviation $=5.33$ ) and conventional funds yielded an average of -1.66 (Standard deviation $=3.94)$. The mean difference of -.50 was however found insignificant due to a lower t-value of -0.52. Lastly, Islamic funds yielded a mean Sharpe measure value of- 0.45 in comparison to mean Sharpe value of -0.27 for conventional funds. This mean difference of -0.18 was found significant ( $\mathrm{t}$-statistics $=-1.98$ ), implying that on average conventional funds performed better in year 2014.

Overall, both Islamic and conventional funds yielded negative average Sharpe measure values for the years from 2010 to 2014, while the performance differences were insignificant for years 2010 to 2013, conventional funds performed better in 2014.

Table 2 provides averages of Sharpe measure of performance for five years from 2010 to 2014 according to the different types of funds. The fund types being considered are Aggressive fixed income, asset allocation, balanced, equity, fund of funds, income, index tracker and money market.

Overall, Sharpe measure mean for year 2010 valued to -0.52 along with a standard deviation of 0.50 (Minimum value $=-0.86$, Maximum value $=0.15$ ). Fund type of Index tracker yielded highest mean value for 2010 
i.e. -0.10 (Standard deviation $=0.04)$, second to which was equity funds with a Sharpe measure mean value of 0.19 along with a standard deviation of 0.15 . Close behind equity funds was one Fund of Funds with Sharpe value of -0.21 . Asset allocation and balanced funds followed performance line with an average of -0.24 (Standard deviations $=.36 \& .21$ respectively). Worst performance was exhibited by money market funds in 2010 , which is represented by the lowest mean

\subsection{Treynor Measure 3}

Treynor measure assesses the performance of a portfolio using excess return over the risk free rate and dividing it to the non-diversifiable risk measure of the market i.e. beta. Table 2 provides the Treynor measure of performance for Islamic and conventional funds

Table 2. Treynor Measure of Performance Fund Nature Wise

\begin{tabular}{|c|c|c|c|c|c|c|c|}
\hline Year & Nature & $\mathbf{N}$ & Mean & Std. Deviation & Mean Difference & $\mathbf{T}$ & Sig. \\
\hline \multirow[t]{2}{*}{2010} & Islamic & 28 & 0.03 & 0.13 & \multirow{2}{*}{-0.38} & \multirow{2}{*}{-0.91} & \multirow{2}{*}{0.37} \\
\hline & Conventional & 74 & 0.41 & 2.19 & & & \\
\hline \multirow[t]{2}{*}{2011} & Islamic & 28 & 0.12 & 1.33 & \multirow{2}{*}{0.11} & \multirow{2}{*}{0.43} & \multirow{2}{*}{0.67} \\
\hline & Conventional & 74 & 0.01 & 0.22 & & & \\
\hline \multirow[t]{2}{*}{2012} & Islamic & 28 & -0.04 & 0.24 & \multirow{2}{*}{-0.03} & \multirow{2}{*}{-0.37} & \multirow{2}{*}{0.71} \\
\hline & Conventional & 74 & -0.02 & 0.33 & & & \\
\hline \multirow[t]{2}{*}{2013} & Islamic & 28 & 0.82 & 8.17 & \multirow{2}{*}{0.69} & \multirow{2}{*}{0.44} & \multirow{2}{*}{0.66} \\
\hline & Conventional & 74 & 0.13 & 2.06 & & & \\
\hline \multirow[t]{2}{*}{2014} & Islamic & 28 & -0.01 & 0.52 & \multirow{2}{*}{-0.09} & \multirow{2}{*}{-0.99} & \multirow{2}{*}{0.33} \\
\hline & Conventional & 74 & 0.08 & 0.37 & & & \\
\hline
\end{tabular}

Islamic funds in 2010 yielded mean Treynor measure value of 0.03 (Standard deviation $=0.13$ ) for year 2010 in comparison to the value of 0.41 (Standard deviation $=2.19$ ) for conventional funds. The mean difference of 0.38 was not found significant (t-statistic $=-0.91$ ). For 2011, mean Treynor measure value of Islamic funds was 0.12 (Standard deviation $=1.33)$ as compared to mean value of .01 (Standard deviation $=0.22)$ for conventional funds. Mean difference of 0.11 was also not found significant (t-statistics $=.43$ ). Treynor measure average for Islamic funds in 2012 was -0.04 (Standard deviation $=0.24$ ) as compared to the average of -0.02 (Standard deviation $=0.33$ ) for conventional funds. The mean difference between average Treynor measure of Islamic and conventional funds was -0.03 , which was insignificant (t-statistics $=-0.37$ ). In subsequent year i.e. 2013, mean Treynor measure for Islamic and conventional funds was 0.82 (Standard deviation $=8.17$ ) and 0.13 (Standard deviation $=2.06$ ) respectively. Mean difference of 0.69 for 2013 was also insignificant $(t-s t a t i s t i c s=0.44)$. Lastly, Islamic funds yielded an average Treynor measure value of -0.01 (Standard deviation $=0.52$ ) and 0.08 (Standard deviation $=0.37$ ) for conventional funds. The mean difference of -0.09 between these two types of funds is also insignificant (t-statistics $=-0.99$ ).

Overall, no significant performance differences were found between Islamic and conventional funds in Pakistan. Further, performance fluctuations were also evident in the analysis with regard to Treynor measure, where higher performance was found associated with higher standard deviation.

Overall, average Treynor measure of all funds in 2010 was 0.31 along with standard deviation of 1.87 . The minimum value in the whole data for Treynor measure in 2010 was -0.78 and maximum value of 18.11 . Considering Treynor measure, best performing fund type was found to be aggressive fixed income with mean Treynor measure of 1.88 (Standard deviation $=4.86$ ). After that comes money market funds with mean value of 0.26 (Standard deviation $=0.42$ ). Worst performance with regard to the Treynor measure was found for balanced funds $($ Mean $=-0.11$, Standard deviation $=0.14)$

\subsection{Jenson's Alpha 4}

Jenson's Alpha conceptualization is consistent with traditional measurement of CAPM. Alpha represents excess returns in comparison to the risk free rate and normal returns as predicted by CAPM. Table 3 provides performance comparisons of Islamic and conventional funds considering Jenson's Alpha. 
Table 3. Jonson's Alpha: Fund Nature Wise

\begin{tabular}{|c|c|c|c|c|c|c|c|}
\hline Year & Nature & $\mathbf{N}$ & Mean & Std. Deviation & Mean Difference & $\mathbf{t}$ & Sig. \\
\hline \multirow[t]{2}{*}{2010} & Islamic & 28 & -0.01 & 0.01 & 0.00 & & \\
\hline & Conventional & 74 & -0.01 & 0.01 & 0.00 & 1.52 & 0.13 \\
\hline \multirow[t]{2}{*}{2011} & Islamic & 28 & -0.02 & 0.01 & 0.00 & & \\
\hline & Conventional & 74 & -0.02 & 0.01 & 0.00 & 0.36 & 0.72 \\
\hline \multirow[t]{2}{*}{2012} & Islamic & 28 & 0.00 & 0.01 & 0.00 & & \\
\hline & Conventional & 74 & 0.00 & 0.01 & 0.00 & 0.36 & 0.72 \\
\hline \multirow[t]{2}{*}{2013} & Islamic & 28 & 0.00 & 0.01 & 0.00 & & \\
\hline & Conventional & 74 & 0.00 & 0.01 & 0.00 & 0.16 & 0.87 \\
\hline \multirow[t]{2}{*}{2014} & Islamic & 28 & 0.00 & 0.00 & 0.00 & & \\
\hline & Conventional & 74 & 0.00 & 0.01 & 0.00 & -1.39 & 0.17 \\
\hline
\end{tabular}

Considering Jenon's Alpha, both Islamic and conventional funds yielded an average value of -.01 with standard deviation of -.01 for both in 2010. Mean difference for both of the funds is .00 . A t-statistics of 1.52 indicates that no significant difference exists in average Alpha values of Islamic and conventional funds in 2010. For the year of 2011, mean value for both Islamic and conventional funds was found to be -0.02 along with standard deviations of 0.01 for both Islamic and conventional funds. T-value for mean difference of zero is only 0.36 , which indicates the Alpha values for both of the natures of the firms is not significantly different. For the year of 2012 , 2013 and 2014, average Alpha value of 0.00 along with standard deviations of 0.01 . The mean difference of 0.00 for all of the three years is insignificant as indicated by respective t-values of 0.36, 0.16 and -1.39 for 2012, 2013 and 2014.

Table 3 provides Jenson's Alpha values for different fund types. Considering 2010, average Alpha value for all of the funds was -0.01 along with a standard deviation of 0.01 (Minimum value $=-0.08$, Maximum value $=$ 0.01). Performance of fund types of aggressive fixed income, fund of funds, income, and money market was depicted by an Alpha value of -0.01 with respective standard deviation of $0.01,-, .00$ and .00 . One the other hand, funds of asset allocation, balanced, equity and index tracker yielded an Alpha average of -0.02 along with respective standard deviation of $0.02,0.01,0.02$ and 0.01 . F-statistics of 1.43 indicated that no significant performance differences existed between different fund types in 2014 considering Jenson's Alpha.

Average Alpha value for overall mutual funds in 2011 was found to be -0.02 along with a standard deviation of 0.01 , with a minimum value of -0.6 and maximum value of .00 . During 2011, performance of money market and income funds was depicted by an average Alpha value of -0.01 for both funds (Standard deviations $=0.00$ for both types). Average Alpha value of aggressive fixed income, asset allocation, balanced, fund of funds and index tracker funds was found to be -0.02 along with a respective standard deviation of $0.02,0.01, .00,-$ and .00 .

\subsection{Information Ratio 5}

Information ratio is measured by subtracting portfolio's return with benchmark's returns divided by standard deviation of these excess returns. The ratio measures the ability of the investor to exploit its information to exceed earned returns from the benchmark's return.

Considering information ratio, both Islamic as well as conventional banks yielded mean value of - -0.40 along with respective standard deviation of .22 and .17 . Mean difference of .00 was not significant as indicated by a tstatistics of -0.09 . For the year of 2011, average information ratio for Islamic fund valued to -0.02 (Standard deviation $=.12$ ) and for conventional funds valued to -.07 . The mean difference of .03 was not significant as indicated by a lower value of t-statistics i.e. 0.99. For 2012, both Islamic and conventional funds yielded average information ratio value of -0.75 along with respective standard deviation of .35 and .39 . The mean difference of .00 was not significant at all as indicated by a t-value of .00. Information ratio yielded a mean value of .56 (Standard deviation $=.16$ ) for Islamic funds in 2013 , while this value was -0.50 for conventional funds (Standard deviation $=.21$ ). The mean difference of -.06 was not significant as indicated by a lower t-value of -1.45. Lastly, in 2014 information ratio valued at $-.42($ Standard deviation $=.12)$ for Islamic funds and at $-.35($ Standard deviation $=.16)$ for conventional funds. The mean difference of -.07 was significant at $5 \%$ level of significance as indicated by a t-statistics of -2.05 . 
Table 4 Information ratio: Fund nature wise

\begin{tabular}{|c|c|c|c|c|c|c|c|}
\hline Year & Nature & $\mathbf{N}$ & Mean & Std. Dev. & Mean Difference & $\mathbf{t}$ & Sig. \\
\hline \multirow{2}{*}{2010} & Islamic & 28 & -0.40 & 0.22 & & & \\
\hline & Conventional & 74 & -0.40 & 0.17 & 0.00 & -0.09 & 0.93 \\
\hline \multirow{2}{*}{2011} & Islamic & 28 & -0.04 & 0.12 & & & \\
\hline & Conventional & 74 & -0.07 & 0.15 & 0.03 & 0.99 & 0.32 \\
\hline \multirow{2}{*}{2012} & Islamic & 28 & -0.75 & 0.35 & & & \\
\hline & Conventional & 74 & -0.75 & 0.39 & 0.00 & 0.00 & 1.00 \\
\hline \multirow{2}{*}{2013} & Islamic & 28 & -0.56 & 0.16 & & & \\
\hline & Conventional & 74 & -0.50 & 0.21 & -0.06 & -1.45 & 0.15 \\
\hline \multirow{2}{*}{2014} & Islamic & 28 & -0.42 & 0.12 & & & \\
\hline & Conventional & 74 & -0.35 & 0.16 & -0.07 & -2.05 & 0.04 \\
\hline
\end{tabular}

Overall, no significant performance differences were witnessed between Islamic and conventional funds for years from 2010 to 2013 . However, performance of conventional funds was better as compared to the Islamic funds in 2014.

\section{Discussion on Performance Comparisons 1}

Overall, year wise performance comparison presents a confusing state, where performance of fund types varies by year and by the performance measures. Results summarized the rankings of the funds with regard to years and also performance measure. Only Sharpe measure yielded consistent results whereby best performers were index trackers, equity, balanced and fund of funds, while performance of money market and income funds remained lower for all of the periods and these performance differences were significant as well. Treynor measure on the other hand yielded insignificant and inconsistent results. Jenson's Alpha yielded significant but inconsistent results and lastly information ratio yielded results somewhat consistent with Sharpe's measure where equity funds remained on the top performing list and money market and income fund remained on the lower side of performance.

This research further found no significant differences between performance of Islamic and conventional funds. Overall, the result of the research depict that Pakistani mutual fund sector should be studied and explored for more similarities and differences with specific reference to as to whether performance measures and models used in the developed world with more mature, larger and more mature markets could effectively be used in mutual fund markets like Pakistan or not.

Table 5 Summary of performance comparisons

\begin{tabular}{|c|c|c|c|c|c|c|}
\hline Measure & Rank & 2010 & 2011 & 2012 & 2013 & 2014 \\
\hline \multirow{5}{*}{$\begin{array}{l}\text { Sharpe } \\
\text { Measure }\end{array}$} & Best & Index & Funds of Fund & Equity & Index Tracker & Index Tracker \\
\hline & 2nd & Fund of & Balanced \& & Balanced \& & Equity & Balanced \\
\hline & $2 \mathrm{nd}$ & Income & Income & Income & Income & Income \\
\hline & Last & Money & Money Market & Money Market & Money & Money Market \\
\hline & Sig. & $>.01$ & $>.01$ & $>.01$ & $>.01$ & $>.01$ \\
\hline \multirow{5}{*}{$\begin{array}{l}\text { Treynor } \\
\text { Measure }\end{array}$} & Best & Aggressi & Aggressive Fixed & Asset Allocation & Income & Money Market \\
\hline & 2nd & Money & Money Market & Equity & Money & Income \\
\hline & $2 \mathrm{nd}$ & Equity & Balanced & Fund of Funds & Equity & Asset Allocation \\
\hline & Last & Balanced & Equity & Index Tracker \& & Asset & Aggressive Fixed \\
\hline & Sig. & Insignific & Insignificant & Insignificant & Insignificant & $>.01$ \\
\hline \multirow{5}{*}{$\begin{array}{l}\text { Jenson's } \\
\text { Alpha }\end{array}$} & Best & Undeter & Income \& Money & Balanced & Index Tracker & Undetermined \\
\hline & 2nd & Undeter & Undetermined & Undetermined & Undetermined & Undetermined \\
\hline & $2 \mathrm{nd}$ & Undeter & Undetermined & Undetermined & Undetermined & Undetermined \\
\hline & Last & Undeter & Equity & Income \& Index & Fund of Funds & Undetermined \\
\hline & Sig. & Insignific & $>.01$ & $>.01$ & $>.01$ & Insignificant \\
\hline \multirow{5}{*}{$\begin{array}{l}\text { Informati } \\
\text { on Ratio }\end{array}$} & Best & Index & Money Market & Equity & Equity & Equity \\
\hline & 2nd & Aggressi & Income & Fund of Funds & Fund of Funds & Fund of Funds \\
\hline & $2 \mathrm{nd}$ & Equity & Asset Allocation & Income & Income & Money Market \\
\hline & Last & Balanced & Equity & Money Market & Money & Index Tracker \\
\hline & Sig. & Insignific & $>.01$ & $>.01$ & $>.01$ & $>.01$ \\
\hline
\end{tabular}


5.1 Impact of Fund Characteristics on Fund Performancde 2

Table 6 Model Summary

\begin{tabular}{|l|llll|}
\hline Model & R & R Square & Adjusted R Square & Std. Error of the Estimate \\
\hline 1 & $.667 \mathrm{a}$ & 0.444 & 0.401 & 0.0383148 \\
\hline a. Predictors: (Constant), Fund Family, Size, Age, Exp. Ratio & \\
\hline
\end{tabular}

Table 6 provides model summary of the regression conducted to assess impact of fund characteristics on fund performance. Fund characteristics considered in the research are expense ratio, fund age, fund size and fund family size. R-square of the model is found to be .444 , which indicates that almost $44 \%$ of the variation in the fund performance. Adjusted R-square of the model is estimated to be 0.401 .

Table 7 ANOVA

\begin{tabular}{|c|c|c|c|c|c|}
\hline Model & Sum of Squares & $\mathrm{df}$ & Mean Square & $\mathrm{F}$ & Sig. \\
\hline Regression & 0.061 & 4 & 0.015 & 10.391 & $.000 \mathrm{~b}$ \\
\hline Residual & 0.076 & 52 & 0.001 & & \\
\hline Total & 0.137 & 56 & & & \\
\hline
\end{tabular}

Table 7 provides ANOVA table for the regression model. F-statistics of the model is estimated to be 10.391, which indicates that the model is good fit at $1 \%$ level of significance.

Table 8 Regression Coefficients

\begin{tabular}{|c|c|c|c|c|c|}
\hline \multirow[t]{2}{*}{ Model } & \multicolumn{2}{|c|}{ Unstandardized Coefficients } & Standardized Coefficients & \multirow[t]{2}{*}{$\mathrm{t}$} & \multirow[t]{2}{*}{ Sig. } \\
\hline & $\mathrm{B}$ & Std. Error & Beta & & \\
\hline (Constant) & 0 & 0.005 & & -0.071 & 0.943 \\
\hline Exp. ratio & -0.721 & 0.116 & -0.661 & -6.205 & 0 \\
\hline Size & 0.027 & 0.089 & 0.06 & 0.303 & 0.763 \\
\hline Age & 0.101 & 0.07 & 0.308 & 1.443 & 0.155 \\
\hline Fund Family & -0.071 & 0.064 & -0.164 & -1.111 & 0.272 \\
\hline
\end{tabular}

Table 8 provides regression coefficients assessing the impact of fund characteristics on fund performance.

Dependent variable of the research was alpha coefficient, while independent variables were expense ratio, size, and age and fund family. First independent variables of the research was expense ratio which yielded a negative impact of expense ratio i.e. management fee on fund performance in Pakistan. The beta coefficient for the relationship is -0.721 along with a t-statistics of -6.205 . A higher $t$-statistics valuing above the threshold of two implies that the relationship is significant. Thus, expense ratio has a significant and negative impact on fund performance in Pakistan.

Second independent variable of the research was fund size, which yielded a beta coefficient of 0.027 along with a t-statistics of 0.303 , implying that the correlation between size and fund performance is positive but insignificant. Next variable under consideration was age, which estimated beta co-efficient of .101 and t-statistics of the relationship is 1.443 , which again deem the impact of age on fund performance to be positive but significant. Last variable of the research was fund family size, which yielded a beta value of -.071 along with a t-value of 1.111 , also demanding the impact of family size on fund performance to be insignificant.

Overall, only variable of expense ratio or management fee was found to have a negative and significant impact on the fund performance, while other variables i.e. size, fund family and age were found insignificant, with regard to their impact on mutual funds.

\section{Conclusion 1}

Pakistan is a developing country with a growing mutual fund market. Although mutual fund industry in Pakistan is very old, but private sector started to aggressively take part in the market after privatization of NIT funds. Mostly, individual investors do not actively participate in the mutual funds and other sophisticated forms of investments due to lack of knowledge, awareness and information. There have been no significant empirical and theoretical contributions in this regard as to better guide investors and fund managers to construct a better portfolio. Further, impact of mutual fund characteristics on fund performance is also investigated by this research. The purpose of this research is rather exploratory and it provides first hand evidence with regard to mutual fund performance and its determinants.

This research considers time from of five years from 2010 to 2014, whereby monthly NAVs of mutual funds were used to compare the performance of mutual funds and its determinants based on funds nature. Four established way of mutual fund performance measurement were employed by the research i.e. Sharpe measure, Treynor measure, Jenson's Alpha and Information ratio. These ratios were calculated for all of the mutual funds considered by the research for each year of the research. Data for the mutual funds was collected from MUFAP 
website. All open-ended funds for which data was available on MUFAP website were considered by the research. Subsequently, funds having NAV's for less than four years were excluded from the research and thus, a total of 102 funds were considered by the research. Performance ratios were compared using ANOVA and independent sample t-test. The research further used fama-french three factor models after the inclusion of fourth factor of momentum as advised by Carhart to estimate the excess returns of each mutual fund for whole of the research period. Data for fund characteristics was collected from the fund manager's reports published monthly by each asset management company. Cross sectional OLS estimation technique was used to assess impact of fund characteristics on fund performance.

This research found inconsistencies of performance measurement for different type of performance measures and also for different years. Sharpe measure yielded consistent results whereby best performers were index trackers, equity, balanced and fund of funds, while performance of money market and income funds remained lower for all of the periods and these performance differences were significant as well. Treynor measure on the other hand yielded insignificant and inconsistent results. Jenson's Alpha yielded significant but inconsistent results and lastly information ratio yielded results somewhat consistent with Sharpe's measure where equity funds remained on the top performing list and money market and income fund remained on the lower side of performance. Further, from fund characteristics, only expense ratio significantly influenced mutual fund performance in Pakistan and that was in a negative manner. Other characteristics considered i.e. size, age and fund family size were found insignificant.

\subsection{Implications of the Research 2}

This research was exploratory in nature, provided a detailed, and first hand evidence with regard to mutual fund performance. Following implication are drawn from this research:

There have been confusing and conflicting evidence with regard to the performance comparisons of different ratios and different years implying that there a need to test the existing measure and models of performance to validate these for the local context.

Determination of the fund performance should be considered in a broader manner where other fund related, market related and economic measures should be taken into account.

Mutual fund industry is growing at a fast pace and many mutual funds are of age less than 3 years. There a serious need to consider the growth factors of mutual funds in this regard.

There is a serious need to realign mutual fund industry according to individual investor demand and needs. Awareness of investors regarding mutual fund industry as a viable investment options is very important in this regard.

\subsection{Recommendations 3}

The researcher in the light of the findings of the research puts following recommendations forward:

Primarily, there is a need to make individual investors aware on the prospects and credentials of mutual funds for improvements in mutual fund industry.

Due to non-presence of bond market in Pakistan, mutual funds lack a significant investment segment. There is a serious need to develop alternative debt markets like sukuk market or separate derivate markets.

Mutual funds could invest in real estate and in derivatives in order to add more characteristics to their portfolio.

The type of mutual fund should not lure investor and investment in mutual funds should be based on thorough analysis of mutual fund's portfolio, exposure, risk and return credentials.

An investor and fund manager should be aware of the fact that different performance measure rely on different mechanism and factors for mutual fund performance calculations. Fund seem lucrative by one performance measure could be a failure according to the other. Therefore, a careful analysis of the portfolio composition of the fund should be made and acted upon accordingly.

\subsection{Limitations and Directions for Future Research 4}

Following are the limitations of the research:

This research only considers mutual funds of open-ended scheme and close-ended schemes and pension fund schemes are avoided by the research.

Fund newly started (age less than 4 years) are excluded from the analysis of the research and relatively mature funds are considered for the analysis in the research.

This research only considered limited set of fund characteristics for determination of fund performance and other market and economic factors are not considered by the research.

With regard to the future research, this research provides a base to the future researchers considering investigating mutual fund industry. Future research could be directed to address limitations of this research. Apart from limitations, following avenues could also be investigated:

Individual investor preferences for different types of the mutual funds could be assessed and new fund scheme 
could be designed, proposed and started accordingly.

Determinants of growth of mutual fund and mutual fund industry could be investigated.

Structural links between growths of mutual fund industry could be established in comparison to economic growth of developing countries like Pakistan.

As entailed previously, there is a serious need to validate the existing models and performance measures in local context and new measures and models could be proposed according to local needs and demands.

\section{References}

Bodson, L., Cavenaile, L., \& Sougné, D. (2013). A global approach to mutual funds market timing ability. Journal of Empirical Finance, 20, 96-101.

Carhart, M. M. (1997). On persistence in mutual fund performance. The Journal of Finance, 52(1), 57-82.

Chen, J., Hong, H., Huang, M., \& Kubik, J. D. (2004). Does fund size erode mutual fund performance? The role of liquidity and organization. The American Economic Review, 94(5), 1276-1302.

Chou, W.-H. (2013). Portfolio preferences across markets: Evidence from mutual fund ownership. International Journal of Banking and Finance, 9(4), 5.

Fama, E. F., \& French, K. R. (1992). The cross - section of expected stock returns. The Journal of Finance, 47(2), $427-465$

Ferreira, M. A., Keswani, A., Miguel, A. F., \& Ramos, S. B. (2013). The determinants of mutual fund performance: A cross-country research. Review of Finance, 17(2), 483-525.

Friend, I., Brown, F. E., Herman, E. S., \& Vickers, D. (1962). A research of mutual funds. US Securities and Exchange Commission, US Government Printing Office, Washington DG.

Gohar, R., Ahmed, S., \& Niazi, U. (2011). Performance comparison of mutual funds in Pakistan. African Journal of Business Management, 5(14), 5583-5593.

Goodwin, T. H. (1998). The information ratio. Financial Analysts Journal, 34-43.

Henriksson, R. D., \& Merton, R. C. (1981). On market timing and investment performance. II. Statistical procedures for evaluating forecasting skills. Journal of business, 513-533.

Huang, J., Sialm, C., \& Zhang, H. (2011). Risk shifting and mutual fund performance. Review of Financial Studies, 24(8), 2575-2616.

Jensen, M. C. (1968). The performance of mutual funds in the period 1945-1964. The Journal of Finance, 23(2), $389-416$.

Kaushik, A., Brinckman, D. E., \& Rose, C. C. (2013). Performance Evaluation and Fund Selection Criteria for Mutual Funds over the Period 2000-2011. Accounting \& Finance Research, 2(3).

Lobell, N. D. (1961). Mutual Fund: A Structural Analysis, The. Va. L. Rev., 47, 181.

Nafees, B., Shah, S. M. A., \& Khan, S. (2011). Performance evaluation of open end and close end mutual funds in Pakistan. African Journal of Business Management, 5(28), 11425-11434.

Pastor, L., \& Stambaugh, R. F. (2001). Liquidity risk and expected stock returns: National Bureau of Economic Research.

Pollet, J. M., \& Wilson, M. (2008). How does size affect mutual fund behavior? The Journal of Finance, 63(6), 2941-2969.

Prajapati, K. P., \& Patel, M. K. (2012). COMPARATIVE RESEARCH ON PERFORMANCE EVALUATION OF MUTUAL FUND SCHEMES OF INDIAN COMPANIES.

Pukki, M. (2012). Do mutual funds time market liquidity? A research on US mutual fund performance.

Raza, S. A., Raza, S. A., \& Zia, A. (2011). Equity mutual funds performance in Pakistan: risk \& return analysis.

Rinne, K., \& Suominen, M. (2014). Mutual Funds' Returns from Providing Liquidity and Costs of Immediacy.

Robinson, D. T., \& Sensoy, B. A. (2011). Cyclicality, performance measurement, and cash flow liquidity in private equity: National Bureau of Economic Research.

Sadka, R. (2012). Hedge-fund performance and liquidity risk. Journal of Investment Management (JOIM), Second Quarter.

Sharpe, W. F. (1964). Capital asset prices: A theory of market equilibrium under conditions of risk*. The Journal of Finance, 19(3), 425-442.

Sharpe, W. F. (1966). Mutual fund performance. Journal of business, 119-138.

Swinkels, L., \& Tjong-A-Tjoe, L. (2007). Can mutual funds time investment styles? Journal of Asset Management, $8(2), 123-132$.

Treynor, J., \& Mazuy, K. (1966). Can mutual funds outguess the market. Harvard business review, 44(4), 131136.

Vidal-García, J., \& Vidal, M. (2012). Do Liquidity and Idiosyncratic Risk Matter?: Evidence from the European Mutual Fund Market.

Wagner, N., \& Winter, E. (2013). A new family of equity style indices and mutual fund performance: Do liquidity and idiosyncratic risk matter? Journal of Empirical Finance, 21, 69-85. 
Yan, X. S. (2008). Liquidity, investment style, and the relation between fund size and fund performance. Journal of Financial and Quantitative Analysis, 43(03), 741-767.

Bailey, W., Kumar, A., \& Ng, D. (2011). Behavioral biases of mutual fund investors. Journal of Financial Economics, 102(1), 1-27.

Chen, J., Hong, H., Jiang, W., \& Kubik, J. D. (2013). Outsourcing mutual fund management: firm boundaries, incentives, and performance. The Journal of Finance, 68(2), 523-558.

Cremers, K. M., \& Petajisto, A. (2009). How active is your fund manager? A new measure that predicts performance. Review of Financial Studies, 22(9), 3329-3365.

Edelen, R., Evans, R., \& Kadlec, G. (2013). Shedding Light on 'Invisible'Costs: Trading Costs and Mutual Fund Performance. Financial Analysts Journal, 69(1), 33-44.

Huang, J., Sialm, C., \& Zhang, H. (2011). Risk shifting and mutual fund performance. Review of Financial Studies, hhr001.

Idzorek, T., Xiong, J., \& Ibbotson, R. (2012). Liquidity Style of Mutual Funds. Available at SSRN 1789906.

Odean, T. (1998a). Are investors reluctant to realize their losses? The Journal of Finance, 53(5), 1775-1798.

Odean, T. (1998b). Do investors trade too much? Available at SSRN 94143.

Parida, S., \& Teo, T. (2011). The impact of more frequent portfolio disclosure on mutual fund performance. Available at SSRN 2097883.

Sialm, C., \& Starks, L. (2012). Mutual fund tax clienteles. The Journal of Finance, 67(4), 1397-1422.

Avramov, D., \& Wermers, R. (2006). Investing in mutual funds when returns are predictable. Journal of Financial Economics, 81(2), 339-377.

Carhart, M. M. (1997). On persistence in mutual fund performance. The Journal of Finance, 52(1), 57-82.

Cremers, K. J. M., \& Petajisto, A. (2009). How Active Is Your Fund Manager? A New Measure That Predicts Performance. Review of Financial Studies, 22(9), 3329-3365. doi: 10.1093/rfs/hhp057

Cremers, M., Ferreira, M., Matos, P., \& Starks, L. (2011). The mutual fund industry worldwide: explicit and closet indexing, fees, and performance. Unpublished working paper. Yale School of Management.

Da, Z., Gao, P., \& Jagannathan, R. (2011). Impatient trading, liquidity provision, and stock selection by mutual funds. Review of Financial Studies, 24(3), 675-720.

Daniel, K., Grinblatt, M., Titman, S., \& Wermers, R. (1997). Measuring mutual fund performance with characteristic - based benchmarks. The Journal of Finance, 52(3), 1035-1058.

Elton, E. J., Gruber, M. J., \& Blake, C. R. (2012). Does mutual fund size matter? The relationship between size and performance. Review of Asset Pricing Studies, ras001.

Fama, E. F., \& French, K. R. (1989). Business conditions and expected returns on stocks and bonds. Journal of Financial Economics, 25(1), 23-49.

Fama, E. F., \& French, K. R. (1992). The cross - section of expected stock returns. The Journal of Finance, 47(2), 427-465.

Grinblatt, M., \& Titman, S. (1993). Performance measurement without benchmarks: An examination of mutual fund returns. Journal of business, 47-68.

Hayat, R., \& Kraeussl, R. (2011). Risk and return characteristics of Islamic equity funds. Emerging Markets Review, 12(2), 189-203.

Humphrey, J. E., \& Lee, D. D. (2011). Australian socially responsible funds: Performance, risk and screening intensity. Journal of Business Ethics, 102(4), 519-535.

Jiang, W. (2003). A nonparametric test of market timing. Journal of Empirical Finance, 10(4), 399-425.

Khorana, A., \& Servaes, H. (2012). What drives market share in the mutual fund industry? Review of Finance, 16(1), 81-113.

Khorana, A., Servaes, H., \& Tufano, P. (2009). Mutual fund fees around the world. Review of Financial Studies, 22(3), 1279-1310.

Mansor, F., \& Bhatti, M. I. (2011). Risk and return analysis on performance of the Islamic mutual funds: evidence from Malaysia. Global Economy and Finance Journal, 4(1), 19-31.

Ornelas, J. R. H., Silva Júnior, A. F., \& Fernandes, J. L. B. (2012). Yes, the choice of performance measure does matter for ranking of us mutual funds. International Journal of Finance \& Economics, 17(1), 61-72.

Treynor, J., \& Mazuy, K. (1966). Can mutual funds outguess the market. Harvard business review, 44(4), 131136. 